\title{
A Comparative Study on the Age Discrimination in Retirement in Poland and South Korea - in Special Consideration of the Linkage between Retirement Age and Pension Eligibility
}

\section{International standards concerning age discrimination in respect of employment and occupation}

\subsection{ILO Convention No 111}

$\tau_{\text {F }}$ or the purpose of ILO Convention No $111^{1}$ the term discrimination $\int$ (Article 1 Para 2) includes:

(1) any distinction, exclusion or preference made on the basis of race, colour, sex, religion, political opinion, national extraction or social origin, which has the effect of nullifying or impairing equality of opportunity or treatment in employment or occupation;

(2) such other distinction, exclusion or preference which has the effect of nullifying or impairing equality of opportunity or treatment in employment or occupation as may be determined by the Member concerned after consultation with representative employers' and workers' organisations, where such exist, and with other appropriate bodies ${ }^{2}$.

* Professor Emeritus, Kookmin University, Seoul, South Korea. He received his Dr. jur. from the University of Bremen, Germany. He was Professor of Law at the Kookmin University, Seoul, Korea. As Honorary President of the Korea Society for Labor Law (KSLL), Korea Labor and Employment Relations Association (KLERA) and the Korean Association of Social Security Law (KASSL), he was elected in 2012 as a Vice-President of the International Society for Labour and Social Security Law (ISL\&SSL).

${ }^{1}$ C111 - Discrimination (Employment and Occupation) Convention, 1958 (No 111), Convention Concerning Discrimination in Respect of Employment and Occupation (Entry into force: 15 June 1960).

${ }^{2}$ Article 1, para. 1, C111. 
The discrimination on the basis of age is not observed.

Article 5, para. 2 ILO C111 stipulates: "Any Member may, after consultation with representative employers' and workers' organisations, where such exist, determine that other special measures designed to meet the particular requirements of persons who, for reasons such as sex, age, disablement, family responsibilities or social or cultural status, are generally recognised to require special protection or assistance, shall not be deemed to be discrimination".

Thus, the prohibition on the basis of age is regulated indirectly in ILO C111.

\subsection{Council Directive 2000/78/EC}

Council Directive 2000/78/EC ${ }^{3}$ states, among others, in recital (25): "The prohibition of age discrimination is an essential part of meeting the aims set out in the Employment Guidelines and encouraging diversity in the workforce. However, differences in treatment in connection with age may be justified under certain circumstances and therefore require specific provisions which may vary in accordance with the situation in Member States. It is therefore essential to distinguish between differences in treatment which are justified, in particular by legitimate employment policy, labour market and vocational training objectives, and discrimination which must be prohibited".

Directive 2000/78 specifically states, in recital (14) that it shall be without prejudice to national provisions laying down the retirement age. The broad discretion apparently granted to States by recital (14) has given rise to much litigation, both in the domestic courts of individual States and before the Court of Justice of the European Union (CJEU) ${ }^{4}$.

The purpose of the Directive 2000/78 is to lay down a general framework for combating discrimination on the grounds of religion or belief, disability, age or sexual orientation as regards employment and occupation, with a view to putting into effect in the Member States the principle of equal treatment ${ }^{5}$.

Directive 2000/78 stipulates justification of differences of treatment on the grounds of age, if, within the context of national law, they are objectively and reasonably justified by a legitimate aim, including legitimate employment policy, labour market and vocational training objectives, and if the means of achieving that aim are appropriate and necessary ${ }^{6}$.

${ }^{3}$ Council Directive 2000/78/EC of 27 November 2000 establishing a general framework for equal treatment in employment and occupation.

4 D. O'Dempsey and A. Beale, Age and Employment, European Commission, 2011, p. 66.

${ }^{5}$ Article 1, Council Directive 2000/78/EC.

${ }^{6}$ Article 6, para. 1, Council Directive 2000/78/EC. 
Furthermore, Member States may provide that the fixing for occupational social security schemes of ages for admission or entitlement to retirement or invalidity benefits, including the fixing under those schemes of different ages for employees or groups or categories of employees, and the use, in the context of such schemes, of age criteria in actuarial calculations, does not constitute discrimination on the grounds of age, provided this does not result in discrimination on the grounds of sex ${ }^{7}$.

\section{The situation in Poland}

\subsection{The effect of the state pension age}

The existence of an adequate pension has been seen as a significant factor of the justification of default retirement ages in the CJEU.

In Poland, the statutory minimum pension age has been 65 for men and 60 for women. By the Act of $2012^{8}$, from 1 January 2013 the retirement age is increasing by a month in January, May and September each year until it reaches 67 for both sexes (for women in 2040, and for men in 2020). For the minimum pension, 25 and 20 years' contributions are required from men and women, respectively.

The employees can work beyond that age but their state pension will be suspended if they continue working for the same employer at the employee's discretion $^{10}$.

\subsection{Rules relating to occupational pension schemes (OPS)}

What is the normal age for OPS payments? Is it possible to defer? Is it possible to work and claim?

In Poland, the occupational pension schemes (OPS) were introduced in 1999 but they are not very widespread. Only approx. 2\% of workforce is covered by Employee's Pension Programmes (PPE) (voluntary collection). The OPS are non-obligatory by law, but the plan must be offered to more than $50 \%$ of the employees in the company. Employee contributions are based on after-tax earnings. Benefits are exempted from the capital gains tax ${ }^{11}$.

7 Article 6, para. 1, Council Directive 2000/78/EC.

8 Act of 11 May on Change of the Act on Pension and Annuities from Social Insurance Fund and some other Acts.

${ }_{9}$ D. Skupień, M. Łaga, and Ł. Pisarczyk, Polish Labour and Social Security Law: the Impact of the Economic Crisis and Demographic Problems, 2014, p. 24, at: http://islssl.org/wp-content/uploads/2014/08/Polish-National-Report.pdf.

10 Articles 24 and 27 of the Act on Retirement.

11 http://www.findyourpension.eu/en/pension_systems/poland/. 
The employees receive pensions from Employee's Pension Programmes at different times under different rules: (1) on a decision by the individual at $60 ;(2)$ on presentation of a decision granting the right to a state pension at $55 ;(3)$ at 70 if they have not previously applied to receive payments and if their employment has been terminated by the employer running the Employee's Pension Programme ${ }^{12}$.

\subsection{Is there a state-imposed (general or sectoral) mandatory retirement age(s)?}

A mandatory retirement age is a specific age at which, no matter what the parties to the employment relationship may want, the employee must retire and the employment relationship comes to an end as a result. Closely related are situations in which the employer can, by law, terminate the employment without the employee's consent at a particular age.

In Poland, there is neither law nor sectoral provision imposing a mandatory retirement age. Neither recent nor planned changes are observed.

\subsection{Facilitating employer compelled retirement and loss of protection against dismissal and other employment protection}

The issue of the extent to which the Directive leaves employers free to impose an internal age upon their employees, and of the extent to which States should provide protection against dismissal in such circumstances, is complicated by the fact that dismissal is a form of less favourable treatment. Many countries apply a general objective justification test to all forms of less favourable treatment on the grounds of age so any particular dismissal may be a proportionate means of achieving a legitimate aim in all the countries in which (1) there is a general justification test; and (2) the constitution or some extraneous legal principle does not prohibit such justification. The general law may render such a dismissal relatively easy to justify.

In Poland, the employer is not permitted to set an age for compelled retirement. The Supreme Court held that the termination of an employment contract cannot be justified solely by reason of the fact that the employee has reached the retirement age and become entitled to a pension. The protection from dismissal and the employment rights are not lost. If there is an additional reason behind the need to dismiss (e.g. redundancy), early selection of people who have a right to the pension in the first place is acceptable ${ }^{13}$.

${ }_{12}$ Article 42, paras 1 and 2, Act of 20 April 2004 on Employee's Pension Programmes (Ustawa z 20 kwietnia 2004 r. o pracowniczych programach emerytalnych).

${ }^{13}$ D. O'Dempsey and A. Beale, Age and Employment..., p. 79. 


\section{The situation in South Korea}

\subsection{The legal framework for prohibition of age discrimination}

According to the National Human Rights Commission Act (NHRCA) of 2001, the term "discriminatory act violating the right to equality" means any of the discriminatory acts committed without reasonable cause based on gender, religion, disability, age, social status, region of birth (including place of birth, first-registered domicile, one's legal domicile, and major residential district where a minor lives until he/she becomes an adult), national origin, ethnic origin, appearance, marital status (i.e. married, single, separated, divorced, widowed, and de facto married), race, skin colour, thoughts or political opinions, family type or family status, pregnancy or birth, criminal record of which effective term of the punishment has expired, sexual orientation, academic background or medical history, etc. ${ }^{14}$

The discriminatory acts comprise the acts of favourable treatment, exclusion, differentiation, or unfavourable treatment of a particular person in employment (including recruitment, hiring, training, placement, promotion, wages, payment of commodities other than wages, loans, age limit, retirement, and dismissal, etc.).

The prohibition of age discrimination in employment is further stipulated with the promotion of the aged employment. The purpose of the Act on Prohibition of Age Discrimination in Employment and Aged Employment Promotion (PADEAEPA) of 1991 is to contribute to the employment security of the aged and to the development of the national economy by prohibiting discrimination in employment on the grounds of age without reasonable causes, and supporting and promoting the employment of the aged so that they can have jobs suitable for their abilities ${ }^{15}$.

According to the PADEAEPA, an employer shall not discriminate against a worker and a person who intends to be a worker on the grounds of age without any reasonable cause in recruitment and employment; provision of wages, and other money and valuables, and welfare benefits; education and training; assignment, transfer or promotion; and retirement or dismissal ${ }^{16}$. In the application of this rule, any results unfavourable to a certain age group, which are caused by applying standards other than age without a reasonable cause, are deemed age discrimination ${ }^{17}$.

14 Article 2, No 3 of the National Human Rights Commission Act of Korea (NHRCA), Act No 6481, established on 24 Ma 2001.

15 Article 1 PADEAEPA.

${ }_{16}$ Article 4-4 (1) PADEAEPA.

17 Article 4-4 (2) PADEAEPA. 
Any of the following cases shall not be considered age discrimination under Article 4-4 ${ }^{18}$ :

(1) Where a certain age limit is inevitably required in consideration of the characteristic of the duties;

(2) Where wages and other money, valuables and welfare benefits are reasonably differentiated according to length of service;

(3) Where a retirement age is set under labour contracts, work rules, collective agreements, etc. pursuant to this Act or other Acts;

(4) Where support measures are taken to maintain and promote the employment of a certain age group pursuant to this Act or other Acts.

The victim of age discrimination under Article 4-4 may file a petition to the National Human Rights Commission (NHRC). If the NHRC judges that there is age discrimination after investigating the petition and recommends the employer, or the head of the relevant authorities, organization or supervisory authorities should take remedial measures, etc., it shall also notify the Minister of Employment and Labor (MOEL) of the details of such recommendation ${ }^{19}$.

If the employer who has been recommended to take remedial measures, etc., by the NHRC fails to comply with such recommendation without any justifiable reasons, and is deemed to inflict serious harm falling under any of the following subparagraphs, the MOEL may issue a corrective order by virtue of his/her authority or at the request of the victim ${ }^{20}$ :

(1) Failure to comply with recommendations for an act of age discrimination involving a number of victims;

(2) Failure to comply with recommendations for repeated acts of age discrimination;

(3) Intentional failure to comply with recommendations, which is aimed at giving disadvantages to the victim;

(4) Other cases prescribed by the Ordinance of the MOEL where a corrective order is needed in view of the contents, amount, etc. of the harm.

The corrective order shall include stoppage of acts of age discrimination; restitution for harm; measures to prevent further recurrence of age discrimination; and other measures prescribed by the Ordinance of the MOEL as required to redress age discrimination ${ }^{21}$.

If the corrective order is issued at the request of a victim, such corrective order shall be issued within three months from the date when the request is received $^{22}$. If the MOEL issues a corrective order, he/she shall give

\footnotetext{
18 Article 4-5 PADEAEPA.

19 Article 4-6 PADEAEPA.

20 Article 4-7 (1) PADEAEPA.

${ }^{21}$ Article 4-7 (2) PADEAEPA.

${ }^{22}$ Article 4-7 (3) PADEAEPA.
} 
a written statement to the employer and victim, respectively, specifying reasons for the corrective order; details of the corrective order; the deadline for redress; and a procedure for filing an appeal against the corrective order $^{23}$.

The MOEL may request the employer who has committed an act of age discrimination to submit a status report on compliance with a corrective or$\mathrm{der}^{24}$. If the employer who has committed an act of age discrimination fails to comply with a corrective order, the victim may report it to the MOEL ${ }^{25}$.

\subsection{Extension of retirement age}

As for now, Korea has no legally binding age limit for workers. Workers in both the public and private sectors generally retire between the ages 56 and 58. According to the Korea Labor Institute, the average retirement age at Korean firms with 300 or more employees was 57.4 in $2010^{26}$.

The revised PADEAEPA of 2013 requires the employer to set the retirement age of workers at 60 or above. Nevertheless, when the employer sets the retirement age of workers below 60 , the retirement age shall be considered to have been set at $60^{27}$. This regulation will be effective on 1 January 2016 for the businesses with 300 workers or more, public institutions, local government-controlled corporations and local government-owned corporations. For the businesses with less than 300 workers and the state and local governments, it will be effective on 1 January $2017^{28}$.

The employer of a business which extends the retirement age and its trade union representing the majority of workers (or the person representing the majority of workers if there is no trade union representing the majority of workers) shall take necessary measures, such as restructuring the wage system, according to the conditions of the business or workplace. The MOEL may provide necessary support, such as employment subsidies, to the employer or workers of the business which takes the necessary measures. The MOEL may also provide support such as consulting for the restructuring of a wage system, etc., to the employer or workers of the business which extends the retirement age to 60 or above ${ }^{29}$.

The employer with 300 or more workers shall submit a status report on the implementation of the retirement age system to the MOEL every

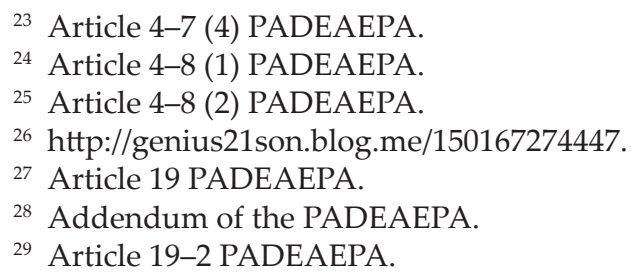


year. If the employer sets the retirement age remarkably low, the MOEL may recommend the employer should extend the retirement age ${ }^{30}$.

If a person who has reached the retirement age wishes to be reemployed in the same workplace, the employer shall strive to reemploy him/ her in an occupation that suits his/her ability to perform duties. In reemploying an aged retiree, the employer may exclude his/her previous service period from producing the continuous service period needed to calculate the retirement pay ${ }^{31}$ and the number of days of annual paid leave ${ }^{32}$, and determine wages differently from the previous ones under an agreement between the parties concerned ${ }^{33}$.

The MOEL may provide necessary support in the form of subsidies to the employer who reemploys retirees or takes other necessary measures to ensure employment security for retirees ${ }^{34}$.

The employer shall make efforts to support job-seeking activities carried out by an aged worker who is going to leave his/her job due to reasons, such as retirement after reaching the retirement age, etc. The MOEL may provide necessary support, such as paying labour costs, subsidies, etc., to the employer who faithfully implements this support measure ${ }^{35}$.

The MOEL shall provide counselling, advice and other necessary cooperation and support in regard of the personnel affairs, wages, etc., of the enterprise following the extension of the retirement age ${ }^{36}$.

\subsection{Conflict around the "wage peak system"}

As mentioned above, the revised PADEAEPA requires that the employer of the business which extends the retirement age and its trade union representing the majority of workers (or the person representing the majority of workers if there is no trade union representing the majority of workers) shall take necessary measures, such as restructuring the wage system, in consideration of the conditions of the business or workplace.

It is presumed that the law-makers passed the bill on the extension of retirement age in compensation for the introduction of a "wage peak system".

Many South Korean companies are still following a seniority-based wage system. Consequently, the extension of the retirement age without reforming the current wage system is feared to add labour costs and to reduce the employment of young workers.

\footnotetext{
30 Article 20 PADEAEPA.

31 Article 34 of the Labor Standards Act.

32 Article 60 of the Labor Standards Act.

${ }^{33}$ Article 21 PADEAEPA.

34 Article 21-2 PADEAEPA.

${ }^{35}$ Article 21-3 PADEAEPA.

${ }^{36}$ Article 22 PADEAEPA.
} 
According to statistics from the MOEL, $71.9 \%$ of companies with 100 or more employees as of 2013 maintained a grade pay, a type of seniority-based wage, and only $16.3 \%$ of companies with 100 or more employees as of 2012 implemented a salary peak system.

The statute does not refer directly to the "wage peak system", but it makes it the duty of the employer and the majority trade union (or the person representing the majority of workers) to take "necessary measures, such as restructuring the wage system" after extension of the retirement age.

Different business groups are adopting different systems. Some of them will apply a wage peak to the annual salary they pay, while others will limit it to the base pay.

Most of the business groups subject to a $10 \%$ cut per year are scheduled to implement a wage peak from the next year. One of them is the Samsung Group, which introduced a wage peak in its subsidiaries. Most of its subsidiaries will start to cut wages in 2016 by reducing them by $10 \% \mathrm{com}$ pared to the previous year, and then doing so again each year for five years in total. In other words, a 56-year-old Samsung Group employee will earn only $90 \%$ of what he did at $55,81 \%$ at age $57,72.9 \%$ at age 58 , and so on. The same calculation method has been adopted by SK Telecom, LG Chem, and KT.

In the meantime, controversy still remains as to the effectiveness of the new system surrounding the issue of how much to cut salaries. In some cases, voluntary retirement is more advantageous for employees because voluntary retirees are to be given a lump sum equivalent to dozens of months of salary.

There seems to be a long way to go in reforming the system under the current law. The Labor Standards Act restricts making changes of employment rules that would be disadvantageous to employees, which means the majority of employees ${ }^{37}$ have to agree on implementing the salary peak system. However, $43.2 \%$ of companies said the employees and labour unions would "oppose" to the salary peak system, which is a downright conflict of interest between the companies and employees.

\subsection{Deferment of pension eligibility}

South Korea was found to have one of the least generous pension systems in the developed world, while suffering its highest rate of senior poverty. According to the Korea Labor Institute the net replacement

37 The trade union representing the majority of workers (or the majority of workers if there is no trade union representing the majority of workers). Article 94 (1) of the Labor Standards Act. 
rate of the Korean elderly reached $45.2 \%$ as of 2011 about $10 \%$ lower than the average rate of countries in the Organisation for Economic Cooperation and Development (OECD) ${ }^{38}$. The net replacement rate is to the level of the post-retirement pension income compared to personal income before retirement.

A number of international labour-related organizations have recommended that countries keep the net replacement rate at around 70 to $80 \%$ to ensure elderly welfare. Among the 34 OECD countries only four countries had lower rates than Korea: Japan New Zealand Ireland and the UK.

For an individual with 40 years of contributions, pension benefits were designed to replace $60 \%$ of earnings until 2007 . Due to the pension system reform, the replacement was reduced to $50 \%$ in 2008 and then is to be reduced $0.5 \%$ every year until making $40 \%$ from 2009 to 2028 . The earnings measure used for computing benefits is a weighted average of individual lifetime earnings, adjusted for wage growth, and economy-wide earnings over the previous three years, adjusted for price inflation. Pension benefits are indexed to price inflation ${ }^{39}$.

Korea had the highest elderly poverty rate in the OECD. The proportion of Korean over $65 \mathrm{~s}$ in poverty was $48.6 \%$, double the figure of Switzerland, which was second on the list. Israel and Chile followed next, with $20.6 \%$ and $20.5 \%$, respectively.

The report also estimated that $74 \%$ of elderly Koreans who were in poverty lived alone. As of 2014, Korea had some 6.4 million senior citizens, accounting for $15.1 \%$ of the population. This is $3.8 \%$ higher than that of 2012. Of these, only about $31 \%$ or some 2 million were employed.

At the same time, the increasing growth rate of the elderly population was at the fastest pace with $4.1 \%$ along with Germany and the US. Japan Germany and Italy had older populations than Korea with over $20 \%$ over the age of 65, while Mexico Turkey and Chile had less than $10 \%$.

When the baby boomers retire soon, the elderly poverty problem will be much more noticeable amid the record-high elderly poverty rate with relatively low pension income. A change in the Korean labour market is needed in order to accept those elderly employees.

With the national pension reform in 2012, Korea, however, had to gradually increase the age of eligibility for old age pension to 65 from 60 , in what could be a move to ease the financial burden from the retiring population.

The age of eligibility for old age pension is 61 from 2013 and increases one year in every five years to reach 65 in 2033. People born between 1953

${ }^{38}$ http://blog.naver.com/hjh6589/220311126049.

39 D. Park, and G.B. Estrada, Emerging Asia's Public Pension Systems: Challenges and Reform Efforts, 2013, p. 37, at: https://www.imf.org/external/np/seminars/eng/2013/oapfad/ pdf/park_ppr.pdf. 
and 1956 will become eligible to claim their benefits when they turn 61, while those born in or after 1969 will not be eligible for the old age pension until the age of $65^{40}$.

Eligible age for old age pension in South Korea (since 2013)

\begin{tabular}{|l|c|c|c|c|c|}
\hline \multicolumn{1}{|c|}{ Year of Birth } & $\mathbf{1 9 5 3 - 1 9 5 6}$ & $\mathbf{1 9 5 7 - 1 9 6 0}$ & $\mathbf{1 9 6 1 - 1 9 6 4}$ & $\mathbf{1 9 6 5 - 1 9 6 8}$ & After 1969 \\
\hline Full Benefit Age (FBA) & 61 & 62 & 63 & 64 & 65 \\
\hline $\begin{array}{l}\text { Early Entitlement Age } \\
(\mathrm{EEA})\end{array}$ & 56 & 57 & 58 & 59 & 60 \\
\hline
\end{tabular}

*Reduced by $6 \%$ each year for early benefit.

The National Pension Service (NPS) did not elaborate on the reasons behind the gradual shift but the change came amid concerns that South Korea's rapidly aging population could put pressure on the country's public pension system.

South Korea's public expenditure on pensions may need to rise to around $7 \%$ of gross domestic product by 2020, over three times as much as the 2007 level of less than $2 \%$, as retiring Koreans will find themselves increasingly dependent on the country's pension system.

A parliamentary report has claimed the NPS could run out of money by 2053 due to the country' low birth rate and aging population. The world's fourth-largest pension fund managed 367 trillion (\$339 billion) won as of the end of April 2012.

South Korea is fast becoming an aged society, in which more than $14 \%$ of the population is 65 or older. Korea became an aging society in 2000, when the ratio exceeded $7 \%$.

South Korea's fertility rate was the world's seventh lowest in 2011, with 1.24 children per woman. It is lower than an average birth rate of 1.74 among members of the OECD.

By $2050,39 \%$ of the Korean population is expected to be over 60 , compared with the current level of $17 \%$.

\subsection{Retirement pension plan}

Other than the national pension scheme, the employer has to set up at least one retirement benefit scheme (RBS) in order to pay benefits to workers after they retire ${ }^{41}$.

${ }^{40}$ H. Jung, M. Pirog, and S.K. Lee, Do Public Pensions Crowd out Private Transfers to the Elderly?: Evidence from South Korea, "Journal of Pension Economics and Finance" [First View Article, Cambridge University Press], 2015, p. 4.

${ }^{41}$ Article 4 (1), Employee Retirement Benefit Security Act of 2005. 
The employer of a newly established business (excluding mergers or splits) after the enforcement date of the Employee Retirement Benefit Security Act (ERBSA) as wholly amended by Act No 10967 (25 July 2011) shall set up a defined benefit retirement pension plan (DBRPP) or defined contribution retirement pension plan (DCRPP) after hearing opinions from the workers' representative ${ }^{42}$ within one year since the establishment of the business ${ }^{43}$.

Notwithstanding the main sentence of Article 4 (1) and Article 5, if the employer fails to establish a retirement benefit scheme or an individual retirement pension plan (IRPP) under Article 25 (1), he/she shall be deemed to have established a retirement pay (severance pay) system under Article $8(1)^{44}$.

The employer who intends to set up a retirement pay system shall set up the system so that it is possible to pay a retiring worker 30 days or more of the average wages for each year of his/her consecutive service as retirement pay ${ }^{45}$.

Korea's retirement pension reserves surpassed 100 trillion won (\$91.1 billion) for the first time in 10 years since the retirement pension system was introduced in December 2005. With the importance of retirement pensions growing along with National Pension and individual pension to prepare for old age life, the size of retirement pensions is expected to grow faster in the near future.

According to the Maeil Business Newspaper's comparison based on the Financial Supervisory Service's data, the amount of retirement pension reserves stood at 107.06 trillion won as of the end of 2014, up $21.2 \%$ from 84.29 trillion won a year ago. The reserves rose sharply in the fourth quarter of last year.

The fast growth of retirement pension reserves is attributed to growing attention to retirement pension among companies and workers after the announcement of a government plan to revitalize private pensions on 27 August 2014. That time, the government announced that companies whose standing workers number 300 people or above are required to subscribe to retirement pension plans after 2016 and the workers' tax deduction benefit will be expanded to up to 3 million won when they make additional payment through defined contribution pension and individual retirement pension (IRP) account from 2015. Until 2014, up to 4 million

${ }^{42}$ The trade union if there is a trade union joined by a majority of workers, and if there is no such trade union - the majority of workers (Article 4 (3), Employee Retirement Benefit Security Act of 2005).

${ }^{43}$ Article 5, Employee Retirement Benefit Security Act of 2005.

${ }^{44}$ Article 11, Employee Retirement Benefit Security Act of 2005.

${ }^{45}$ Article 8 (1), Employee Retirement Benefit Security Act of 2005. 
won that combines the IPR and retirement pension was covered for tax reduction benefit.

As more workers pay attention to tax-benefited plans in the course of year-end tax adjustments, retirement pension reserves will increase at a faster clip. During the first 40 days of 2015, more than 800 billion won came into retirement pension funds.

\section{Conclusion}

In Poland, there is neither law nor sectoral provision imposing a mandatory retirement age, while in South Korea the revised Act on Prohibition of Age Discrimination in Employment and Aged Employment Promotion (PADEAEPA) of 2013 requires the employer to set the retirement age of workers at 60 or above.

In Poland, the statutory minimum pension age has been 65 for men and 60 for women. By the Act of 2012, from 1 January 2013 the retirement age has been increasing by a month in January, May and September each year until it reaches 67 for both sexes (for women in 2040, and for men in 2020). For the minimum pension, 25 and 20 years' contributions are required from men and women, respectively. The employees can work beyond that age but their state pension will be suspended if they continue working for the same employer at the employee's discretion.

In South Korea, the eligible age for old age pension has been 61 since 2013 and increases one year in every five years to reach 65 in 2033. People born between 1953 and 1956 will become eligible to claim their benefits when they turn 61, while those born in or after 1969 will not be eligible for the pension until the age of 65 .

In Poland, employees receive pensions from Employee's Pension Programmes (voluntary collection) at different times under different rules: (1) on a decision by the individual at 60 ; (2) on presentation of a decision granting the right to a state pension at 55; (3) at 70 if they have not previously applied to receive payments and if their employment has been terminated by the employer running the Employee's Pension Programme.

In Korea, the employer has to set up at least one retirement benefit scheme (RBS). The employer of a newly established business after the enforcement date of the ERBSA as wholly amended (25 July2011) shall set up a DBRPP or DCRPP. If the employer fails to establish a RBS or an IRPP, he/she shall be deemed to have established a retirement pay (severance pay) system in order to pay a retiring worker 30 days or more of the average wages for each year. 
While the OPS in Poland plays a minor role, the RBS in South Korea has a significant impact on the living of retirees. It is a future task for South Korea, however, to fill in the gap between the retirement age and the pension eligibility age.

\section{Bibliography}

Jung H., Pirog M., Lee S.K., Do Public Pensions Crowd out Private Transfers to the Elderly?: Evidence from South Korea, "Journal of Pension Economics and Finance" [First View Article, Cambridge University Press] 2015.

Noh S., Changes in Public Pension Policy in South Korea, 1986-1988: Applying Two Theories of Policy Change, a dissertation submitted to the Faculty of the Columbian College of Arts and Sciences of the George Washington University, 2004.

O’Dempsey D., Beale A., Age and Employment, European Commission, 2011.

Park D., Estrada G.B., Emerging Asia's Public Pension Systems: Challenges and Reform Efforts, 2013, at: http://www.imf.org/external/np/seminars/eng/2013/oapfad/pdf/park_ppr. pdf.

Skupień D., Łaga M., Pisarczyk Ł., Polish Labour and Social Security Law: the Impact of the Economic Crisis and Demographic Problems, 2014, at: http://islssl.org/wp-content/ uploads/2014/08/Polish-National-Report.pdf.

http://blog.naver.com/hjh6589/220311126049.

http://www.findyourpension.eu/en/pension_systems/poland/.

http://genius21son.blog.me/150167274447.

\section{Studium porównawcze dyskryminacji ze względu na wiek w Polsce i Korei Południowej ze szczególnym uwzględnieniem związku między wiekiem emerytalnym i nabyciem prawa do emerytury}

\section{Streszczenie}

Polskie prawo nie narzuca obowiązkowego wieku emerytalnego, podczas gdy w Korei Południowej zmieniona ustawa o zakazie dyskryminacji w zatrudnieniu i popieraniu zatrudnienia z 2013 r. wymaga, aby pracodawca wyznaczył wiek przejścia na emeryturę pracowników w wieku 60 lat i powyżej.

W Polsce minimalny wiek przejścia na emeryturę wynosi 65 lat dla mężczyzn i 60 dla kobiet, Z mocy ustawy z 2012 r., od 1 stycznia 2013 r. wiek emerytalny wzrasta o miesiąc w styczniu, maju i wrześniu każdego roku aż do osiągnięcia 67 lat dla obydwu płci (kobiety w 2040 r., mężczyźni w 2020 r.). Do uzyskania minimalnej emerytury wymaga się 25 i 20 lat składkowych odpowiednio od mężczyzn i kobiet.

W Korei Południowej wiek emerytalny wynosi 61 lat od 2013 r. i zwiększa się o jeden rok co pięć lat aż do osiągnięcia 65 lat w 2033 r. Osoby urodzone między 1953 a 1956 r. będą mogły dochodzić emerytur gdy osiągną 61 lat, podczas gdy urodzeni po 1969 r. nie uzyskają ich przed 65. rokiem życia. 
A Comparative Study on the Age Discrimination in Retirement...

O ile zawodowe systemy emerytalne (occupational pension schemes) odgrywają w Polsce niewielką rolę, w Korei Południowej system świadczeń emerytalnych (retirement benefit scheme) odgrywa ważną rolę w utrzymaniu emerytowanych osób. Zadaniem na przyszłość dla Korei Południowej jest wypełnienie luki między wiekiem emerytalnym i wiekiem nabycia prawa do emerytury.

Tłumaczenie z języka angielskiego - Zbigniew Hajn 